\title{
The Cortical Matrix of Femur in Adult-Aged Wistar Rats is Critically Affected by Maternal Malnutrition During Lactation Period
}

\author{
La Matriz Cortical del Fémur en Ratas Wistar de Edad Adulta se ve Críticamente \\ Afectada por la Malnutrición Materna Durante el Período de Lactancia
}

\begin{abstract}
Marcio Antonio Babinski ${ }^{1}$; Marcio Vinicius Viana Andrade ${ }^{1}$; Mario Augusto Sereno Fernandes ${ }^{1}$; Jorge Gilberto Cipriano Mendes'; Monique da Silva Dias Babinski²; Lucas Alves Sarmento Pires² \& Vinicius Schott Gameiro²
\end{abstract}

BABINSKI, M A.; ANDRADE, V. M. V.; FERNANDES, M. A. S.; MENDES, J. G. C.; BABINSKI, M. S. D.; PIRES, L. A. S. \& GAMEIRO, V.S. The cortical matrix of femur in adult-aged Wistar rats is critically affected by maternal malnutrition during lactation period. Int. J. Morphol., 36(4):1285-1289, 2018.

SUMMARY: Osteoporosis is associated with poor dietary habits. Malnutrition is characterized as a deficit on the intake of necessary nutrients that are essential for optimal health maintenance. It is known that malnutrition during the lactation period can affect the offspring. The present study aims to evaluate the chronic effects caused by maternal energy-protein restriction during lactation period in the offspring. At parturition, Wistar rat dams were divided in three groups: (1) Control group (C) - which received a $23 \%$ protein diet without restrictions; (2) Protein-Energy restriction group (PER)- which received a $8 \%$ protein diet; (3) Energy restriction group (ER) which received a $23 \%$ protein diet in limited amounts, according to the ingestion of the second group. Each group had 12 pups. After weaning, all pups received free access to a $23 \%$ protein diet until 180 days and then were euthanized. Their femur was excised, decalcified, histologically processed and analyzed under a microscope. The measurements of the osteon lacunae on the C, ER and PER groups were, respectively: $2.1 \mu \mathrm{m}, 10.9 \mu \mathrm{m}$ and $14.7 \mu \mathrm{m}(\mathrm{p}<0.05)$. A poor ingestion of proteins and calories during lactation period provoked critical and permanent changes on the bone matrix of the femur, which simulated osteoporosis.

KEY WORDS: Bone remodeling, Bone matrix, Undernutrition, Osteoporosis, Wistar rats.

\section{INTRODUCTION}

Conditions such as osteopenia and osteoporosis are commonly associated with pathological (or fragility) fractures - which possess a high incidence in women and the elderly (Burge et al., 2007; Court-Brown et al., 2014; Willeumier et al., 2017). These diseases cause morphological changes in bony tissue, which in turn leads to loss of its function. Furthermore, both illnesses are associated with inadequate dietary habits (Pignolo et al., 2010; Warensjö Lemming et al., 2017).

Malnutrition (or undernutrition) is defined as a deficit on the intake of necessary nutrients that are essential for optimal health maintenance. It is not only a product of noningestion of food, since irregular dietary habits such as excessive fast food ingestion can cause this condition (Ahsan et al., 2017; Kavle et al., 2018). Despite numerous governmental programs and campaigns, there is still a high incidence of pregnant and lactating women that have an inadequate nutrient intake (Black et al., 2013; Haileslassie et al., 2013; Jeong et al., 2017).

Experimental studies that addressed maternal malnutrition during lactation period showed that this condition can inflict significant changes on bone growth and function in their offspring (Brasil et al., 2005; Fernandes et al., 2007; Fernandes et al., 2008; Babinski et al., 2016; Confortim et al., 2017).

Thus, due to these morphological changes on bony tissue caused by maternal malnutrition during the lactation period associated with the fact that pathological (or fragility) fractures are among the most common types of lesions among osteoporotic and osteopenic patients, the study of maternal malnutrition during lactation period is essential (CourtBrown et al.; Babinski et al.).

\footnotetext{
${ }^{1}$ Orthopedics and Traumatology Department, Salgado Filho Municipal Hospital, Rio de Janeiro, Brazil.

${ }^{2}$ Programa de Pós-Graduação em Ciências Médicas, Universidade Federal Fluminense, Rio de Janeiro, Brazil.
} 
BABINSKI, M A.; ANDRADE, V. M. V.; FERNANDES, M. A. S.; MENDES, J. G. C.; BABINSKI, M. S. D.; PIRES, L. A. S. \& GAMEIRO, V. S. The cortical matrix of femur in adult-aged Wistar rats is critically affected by maternal malnutrition during lactation period. Int. J. Morphol., 36(4):1285-1289, 2018.

The study presented herein aims to investigate the effects of maternal malnourishment during lactation period by a histological and morphometric analysis of the cortical dimensions of the femur in adult aged Wistar rats.

\section{MATERIAL AND METHOD}

This study was approved by the Animal Care and Use Committee of the State University of Rio de Janeiro. All work presented herein were in accordance with the American Physiological Society guidelines (HowardJones, 1985; Bayne, 1996).

Six female Wistar rats mated with three male rats ( 2 females to 1 male). After mating, the six female rats were divided in three distinct groups: the control group (C), which had free access to a standard laboratory diet (in grams per $100 \mathrm{~g}$ ) containing $23 \%$ protein, $68 \%$ carbohydrate, $5 \%$ lipid, $4 \%$ salts and $0.4 \%$ vitamins, and a total of $17,038.7(\mathrm{~kJ} / \mathrm{kg})$ energy; the protein-energyrestricted group (PER), which had free access to an isoenergetic, protein-restricted diet containing $8 \%$ protein; and the energy-restricted group (ER), which was fed with a standard laboratory diet in restricted quantities, which was calculated based on average ingestion of the PER group. This calculi allows comparison between both groups, as previous studies showed that the PER group consumed about $60 \%$ of the amount consumed by the control group, despite the free access to food (Babinski et al.).

Excess pups were removed so that only six pups were kept per dam, since it has been showed to improve the lactation potential of the dam (Fishbeck \& Rasmussen, 1987), thus there were 12 pups per group. All pups showed good health condition. The diet was formulated to match the requirements of the American Institute of Nutrition AIN- 93G recommendation for rodent diets (Reeves et al., 1993).

The maternal malnutrition ended at weaning (21 days post-partum) and the pups were housed in groups of three animals per cage and were given unlimited access to the same diet that was used in the $\mathrm{C}$ group and adlibitum water until adult age (day 180). Then, the animals were anesthetized with a lethal thiopental anesthesia $(0.15$ $\mathrm{mL} / 100 \mathrm{~g} /$ body weight), fixed with a $10 \%$ formalin solution (perfused through the left ventricle with buffered saline) and the right femurs of the specimens were excised.

After the excision, they were placed in a $10 \%$ formaldehyde solution for $24 \mathrm{~h}$, then, they were decalcified (EDTA). Histological process was routinely performed in order to include the samples in paraffin blocks. Then, $10 \mu \mathrm{m}$ thick transversal sections were performed at proximal epiphysis and stained with Hematoxylin/Eosin.

The histological samples were analyzed and quantified according to Nguyen et al. (2017). The microscopic images presented herein had a 400X increase. The areas of the cortical bone that were occupied by lacunae and osteocytes were measured on the three groups. This step was performed with the aid of the Image JÒ software, and the results are presented in micrometers $(\mu \mathrm{m})$.

Data was reported as mean \pm standard deviation (SD). Statistical significance of experimental observations was determined by the ANOVA one-way analysis of variance, followed by post-hoc test of Newman-Keuls to compare the three groups $(\mathrm{p}<0.05$ was considered significant). All statistical analysis was done using GraphPad Prism 6 software (GraphPad Inc., CA, USA).

\section{RESULTS}

According to the histological analysis, the control group displayed regular cortical bone tissue and matrix. The osteocytes completely occupied the lacunae and developing Havers's canals were seen (Fig. 1).

In comparison, the ER group had a less dense and irregular cortical bone, as there were enlarged lacunae with regular osteocytes in its interior. Furthermore, it was also observed irregular lacunae with significant size increase and signs of bone remodeling (Fig. 2).

On the PER group, it was seen that the cortical tissue had an increase in the number of lacunae - which possessed larger areas and no osteocytes (Fig. 3). There were also signs of bone remodeling and bone resorption (Fig. 4). The osteocytes were abundant in larger lacunae, which indicated an increase of cellular death (Fig. 5).

Histomorphometric analysis of the lacunae displayed a mean of $2.1 \mu \mathrm{m}, 10.9 \mu \mathrm{m}$ and $14.7 \mu \mathrm{m}$ on the $\mathrm{C}$, ER and PER groups respectively. These differences were statistically significant $(\mathrm{p}<0.05)$. When compared to the $\mathrm{C}$ group, the ER and PER measurements were statistically significant. There was also a significant increase of the cortical bone osteon area $(\mu \mathrm{m}): \sim 400 \%$ for the RC group and $\sim 600 \%$ for the PER group. 


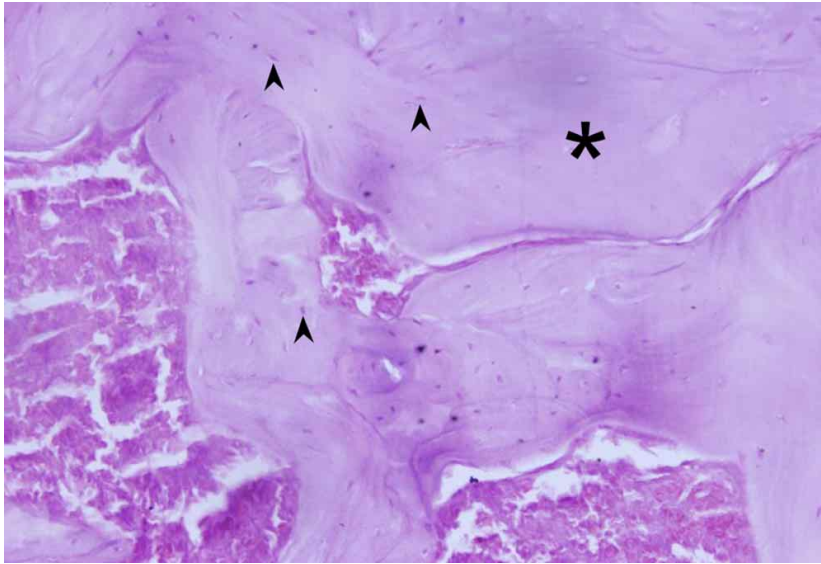

Fig. 1. Cortical tissue of the femur (control group). The compact bone is seen $(*)$ with regular sized lacunae. The arrowheads are depicting regular osteocytes. H\&E stain/400X magnification.

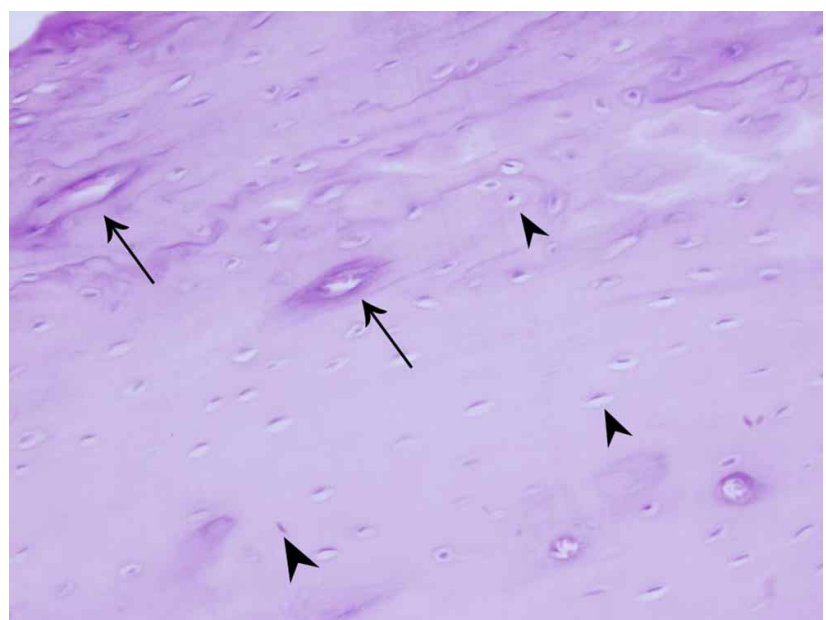

Fig. 2. Cortical tissue of the femur (energy restriction group). Irregular sized and empty lacunae can be seen (black arrows). In addition, irregular sized lacunae are depicted in black arrowheads. H\&E stain/400X magnification.

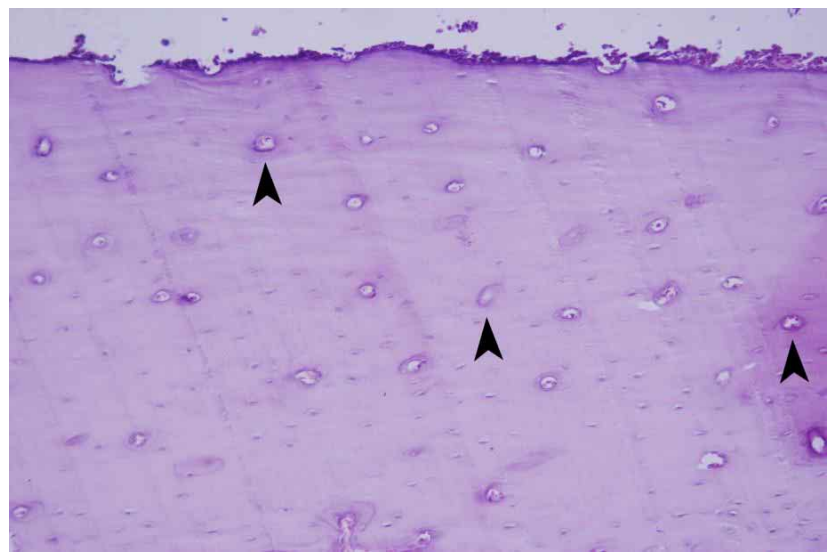

Fig. 3. Cortical tissue of the femur (protein-energy restriction group). Note the large number of lacunae with signs of bone resorption at the edges, which are intensely stained (black arrowheads). H\&E stain/400X magnification.

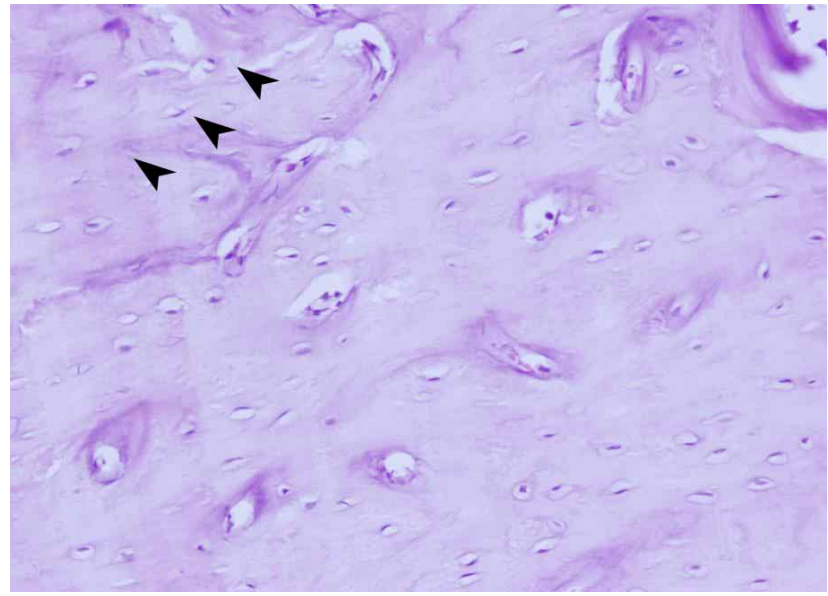

Fig. 4. Cortical tissue of the femur (protein-energy restriction group). Note the large number of irregular and coalescing lacunae (black arrowheads) with necrotic osteocytes inside. H\&E stain/ 400X magnification.

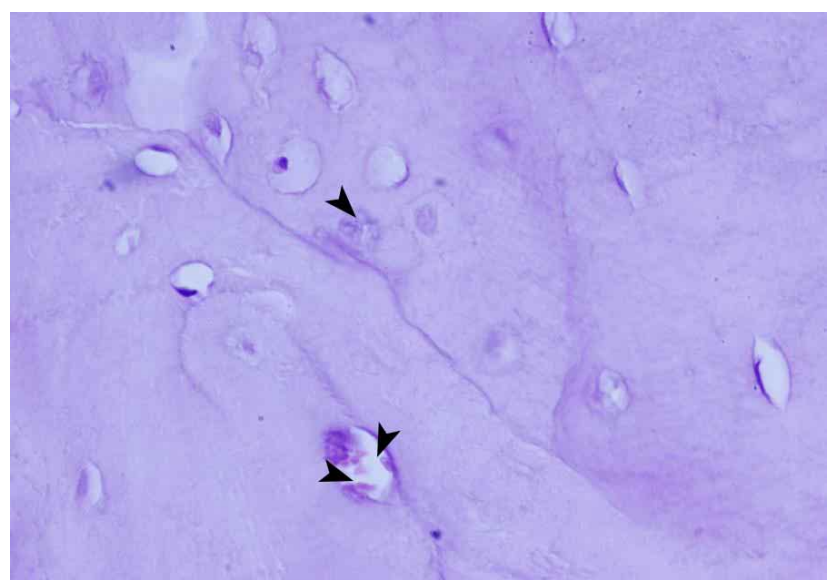

Fig. 5. Cortical tissue of the femur (protein-energy restriction group). Osteocyte death can be observed in irregular lacunae (black arrowheads). H\&E stain/1000X magnification.

\section{DISCUSSION}

It is known that breastfeeding is essential for the correct development of the newborn (Black et al.). The quality of the milk is subject to the mother's dietary habits, thus, a good maternal nutrition is essential to provide optimal milk for its offspring (Plecas et al., 2014; Kavle et al.).

Development of the tissues begin during the intrauterine phase, although, after birth, these organs and cells are under the influence of environmental and dietary habits, thus, proper breastfeeding is necessary (Luna et al., 2016). 
Hence, the first weeks of life for the newborn are critical. Maternal malnutrition during this timeframe can cause difficulty for the bone tissue to develop in short and long terms - previous experimental studies demonstrated the harmful effects of maternal malnutrition during the lactation period in bone tissue of the offspring. Under these circumstances, the pups which were breastfed by a malnourished mother had an underdevelopment of multiple bones, such as the tibia, mandible, cranium and femur (Fernandes et al., 2007; Fernandes et al., 2008; Degani Junior et al., 2011; Babinski et al.; Luna et al.; Confortim et al.). Moreover, the maternal malnutrition during the gestational period has also been shown to cause detrimental effects on its offspring (Alippi et al., 2002; Lee et al., 2016; Confortim et al.).

In humans, maternal malnutrition during pregnancy has been shown to be associated with the late onset of diseases such as osteoporosis (Hyde etal., 2017). Thus, the metabolic programming theory has been gaining recent attention (Dennison et al., 2010; Barker, 2012).

Osteoporosis disrupts the normal arrangement of the bone, as is characterized as low bone mass and microarchitectural deterioration of bone tissue, thus, an osteoporotic bone is more susceptible to fractures and more prone to be damaged during orthopedic procedures (Dennison et al.; Court-Brown et al.; Babinski et al.).

According to the analysis presented herein, there were several alterations on bone matrix of the ER and PER groups. This might indicate that rats that are breastfed by malnourished mothers may develop a disturbance of bone metabolism in the future, in which bone resorption is increased (predominance of osteoclasts) and bone consolidation is decreased. This fact led us to believe that our experiment simulated osteoporosis type II, which could not be reversed with nutritional reposition.

There is a lack of experimental studies regarding the chronic effects of maternal malnutrition during lactation period (e.g. rats that received regular diet after being fed by a malnourished mother). A study performed by Babinski et al. showed that the femur was significantly affected by malnutrition during lactation period, and the morphological effects remained until the adult life of the animals, even after receiving unlimited amounts of a diet with protein and energy after weaning. Furthermore, their study also presented significant alterations of the head and anatomical neck diameters, together with alterations of the cervical-diaphyseal angle in rats from ER and PER groups, in comparison to the control group.
The present study demonstrated that catch-up growth is not possible in the offspring that is subject to maternal malnutrition during lactation period. This is in accordance with several studies (Cesani et al., 2003; Babinski et al.), although there are studies that indicate otherwise (Jones et al., 2011), thus, there is still no consensus on this matter.

\section{CONCLUSIONS}

In summary, maternal protein-energy malnutrition during lactation provokes critical and irreversible changes on bone matrix of the femur in rat offspring. Diet regulation did not reversed the effects caused by the maternal malnutrition, thus the metabolic programming theory should be further expanded to the lactation period as well.

Our results showed that the experimental model was viable in order to reproduce previous results (Fernandes et al., 2007; Fernandes et al., 2008; Degani Junior et al.; Babinski et al.) Furthermore, the present study reiterates the importance of a protein-energy adequate diet to the breastfeeding mother during gestational and lactation periods.

BABINSKI, M A.; ANDRADE V, M. V.; FERNANDES, M. A. S.; MENDES, J. G. C.; BABINSKI, M. S. D.; PIRES, L. A. S. \& GAMEIRO, V. S. La Matriz cortical del fémur en ratas Wistar de edad adulta se ve críticamente afectada por la malnutrición materna durante el período de lactancia. Int. J. Morphol., 36(4):1285-1289, 2018.

RESUMEN: La osteoporosis se asocia con malos hábitos alimenticios. La desnutrición se caracteriza como un déficit en la ingesta de los nutrientes necesarios que son esenciales para un mantenimiento óptimo de la salud. Se sabe que la malnutrición durante el período de lactancia puede afectar a la descendencia. El presente estudio tiene como objetivo evaluar los efectos crónicos causados por la restricción energética-proteína materna durante el período de lactancia en la descendencia. En el parto, las hijas de rata Wistar se dividieron en tres grupos: (1) grupo control (C) - que recibió una dieta con $23 \%$ de proteína sin restricciones; (2) Grupo restricción de energía de proteína (PER) - que recibió una dieta con $8 \%$ de proteína; (3) Grupo restricción de energía (ER) - que recibió una dieta de $23 \%$ de proteína en cantidades limitadas, de acuerdo con la ingestión del segundo grupo. Cada grupo tenía 12 crías. Después del destete, todas las crías recibieron acceso libre a una dieta con $23 \%$ de proteína hasta 180 días y luego fueron sacrificadas. Su fémur fue extirpado, descalcificado, procesado histológicamente y analizado bajo un microscopio. Las mediciones de las lagunas de osteón en los grupos C, ER y PER fueron, respectivamente: $2,1 \mathrm{~mm}, 10,9 \mathrm{~mm}$ y $14,7 \mathrm{~mm}$ (p $<0,05)$. Una mala ingesta de proteínas y calorías durante el período de lactancia provocó cambios críticos y permanentes en la matriz ósea del fémur, que simulaba osteoporosis.

PALABRAS CLAVE: remodelación ósea; Matriz ósea; Desnutrición; Osteoporosis; Ratas Wistar. 


\section{REFERENCES}

Ahsan, S.; Mansoori, N.; Mohiuddin, S. M.; Mubeen, S. M.; Saleem, R. \& Irfanullah, M. Frequency and determinants of malnutrition in children aged between 6 to 59 months in district Tharparkar, a rural area of Sindh. J. Pak. Med. Assoc., 67(9):1369-73, 2017.

Alippi, R. M.; Meta, M. D.; Olivera, M. I.; Bozzini, C.; Schneider, P.; Meta, I. F. \& Bozzini, C. E. Effect of protein-energy malnutrition in early life on the dimensions and bone quality of the adult rat mandible. Arch. Oral Biol., 47(1):47-53, 2002.

Babinski, M. S. D.; Ramos, C. F.; Fernandes, R. M. P.; Cardoso, G. P. \& Babinski, M. A. Maternal malnutrition diet during lactation period leads to incomplete catch-up growth in femur of the pups at adulthood. Int. J. Morphol., 34(1):71-7, 2016.

Barker, D. J. P. Sir Richard Doll Lecture. Developmental origins of chronic disease. Public Health, 126(3):185-9, 2012.

Bayne, K. Revised Guide for the Care and Use of Laboratory Animals available. American Physiological Society. Physiologist, 39(4):199, 208-11, 1996.

Black, R. E.; Victora, C. G.; Walker, S. P.; Bhutta, Z. A.; Christian, P.; de Onis, M.; Ezzati, M.; Grantham-McGregor, S.; Katz, J.; Martorell, R.; Uauy, R. \& Maternal and Child Nutrition Study Group. Maternal and child undernutrition and overweight in low-income and middle-income countries. Lancet, 382(9890):427-51, 2013.

Brasil, F. B.; Faria, T. S.; Costa, W. S.; Sampaio, F. J. \& Ramos, C. F. The pups' endometrium morphology is affected by maternal malnutrition during suckling. Maturitas, 51(4):405-12, 2005.

Burge, R.; Dawson-Hughes, B.; Solomon, D. H.; Wong, J. B.; King, A. \& Tosteson, A. Incidence and economic burden of osteoporosis-related fractures in the United States, 2005-2025. J. Bone Miner. Res., 22(3):465-75, 2007.

Cesani, M. F.; Orden, B.; Zucchi, M.; Muñe, M. C.; Oyhenart, E. E. \& Pucciarelli, H. M. Effect of undernutrition on the cranial growth of the rat. An intergenerational study. Cells Tissues Organs, 174(3):129-35, 2003.

Confortim, H. D.; Jerônimo, L. C.; Centenaro, L. A.; Pinheiro, P. F.; Matheus, S. M. \& Torrejais, M. M. Maternal protein restriction during pregnancy and lactation affects the development of muscle fibers and neuromuscular junctions in rats. Muscle Nerve, 55(1):109-15, 2017.

Court-Brown, C. M.; Heckman, J. D.; McQueen, M. M.; Ricci, W. M.; Torneta III, P. \& McKee, M. D. (Eds.). Rockwood and Green's Fractures in Adults. $8^{\text {th }}$ ed. Philadelphia, Wolters Kluwer Health, 2014.

Degani Junior, H. V. M.; Nunes, V. A.; Bezerra, E. C.; Ramos, C. F.; Rodrigues, M. R.; Abidu-Figueiredo, M.; Cardoso, G. P. \& Babinski, M. A. Maternal food restriction during lactation reduces mandible growth of the female offspring in adulthood: Experimental and morphometric analysis. Int. J. Morphol., 29(2):598-603, 2011.

Dennison, E. M.; Cooper, C. \& Cole, Z. A. Early development and osteoporosis and bone health. J. Dev. Orig. Health Dis., 1(3):142-9, 2010.

Fernandes, R. M. P.; Abreu, A. V.; Schanaider, A.; Soares Jr., E. R.; Pejanha, G. C. A.; Babinski, M. A. \& Ramos, C. F. Effects of protein and energy restricted diet during lactation leads to persistent morphological changes on tibia growth in the weaned pups. Int. J. Morphol., 25(3):565-71, 2007.

Fernandes, R. M.; Abreu, A. V.; Silva, R. B.; Silva, D. F.; Martinez, G. L.; Babinski, M. A. \& Ramos, C. F. Maternal malnutrition during lactation reduces skull growth in weaned rat pups: experimental and morphometric investigation. Anat. Sci. Int., 83(3):123-30, 2008.

Fishbeck, K. L. \& Rasmussen, K. M. Effect of repeated reproductive cycles on maternal nutritional status, lactational performance and litter growth in ad libitum-fed and chronically food-restricted rats. J. Nutr., 117(11):1967-75, 1987.

Haileslassie, K.; Mulugeta, A. \& Girma, M. Feeding practices, nutritional status and associated factors of lactating women in Samre Woreda, South Eastern Zone of Tigray, Ethiopia. Nutr. J., 12:28, 2013.

Howard-Jones, N. A CIOMS ethical code for animal experimentation. WHO Chron., 39(2):51-6, 1985.

Hyde, N. K.; Brennan-Olsen, S. L.; Bennett, K.; Moloney, D. J. \& Pasco, J. A. Maternal nutrition during pregnancy: Intake of nutrients important for bone health. Matern. Child Health J., 21(4):845-51, 2017.

Jeong, G.; Park, S. W.; Lee, Y. K.; Ko, S. Y. \& Shin, S. M. Maternal food restrictions during breastfeeding. Korean J. Pediatr., 60(3):70-6, 2017.

Jones, D. C.; Bernstein, M. \& German, R. Z. Catch-up and targeted growth following variable duration protein restriction: effects on bone and body mass. J. Morphol., 272(4):485-96, 2011.

Kavle, J. A.; Mehanna, S.; Khan, G.; Hassan, M.; Saleh, G. \& Engmann, C. Program considerations for integration of nutrition and family planning: Beliefs around maternal diet and breastfeeding within the context of the nutrition transition in Egypt. Matern. Child Nutr. 14(1):e12469, 2018.

Lee, S.; You, Y. A.; Kwon, E. J.; Jung, S. C.; Jo, I. \& Kim, Y. J. Maternal food restriction during pregnancy and lactation adversely affect hepatic growth and lipid metabolism in three-week-old rat offspring. Int. J. Mol. Sci., 17(12):E2115, 2016.

Luna, M. E.; Quintero, F. A.; Cesani, M. F.; Fucini, M. C.; Guimarey, L. M.; Prio, V. \& Oyhenart, E. E. Craneofacial effect of prenatal growth retardation and postnatal undernutrition in craniofacial growth. Rev. Argent. Antropol. Biol., 18(1), 2016. Available from: Disponible en: https://revistas.unlp.edu.ar/raab/article/view/2047

Nguyen, L.; Tosun, A. B.; Fine, J. L.; Lee, A. V.; Taylor, D. L. \& Chennubhotla, S. C. Spatial statistics for segmenting histological structures in $\mathrm{H} \& \mathrm{E}$ stained tissue images. I. E. E. E. Trans. Med. Imaging, 36(7):1522-32, 2017.

Pignolo, R. J.; Keenan, M. A. \& Hebela, N. M. (Eds.). Fractures in the Elderly: A Guide to Practical Management. New York, Springer Science+Business Media, 2010.

Plecas, D.; Plesinac, S. \& Kontic Vucinic, O. Nutrition in pregnancy: basic principles and recommendations. Srp. Arh. Celok. Lek., 142(1-2):12530, 2014.

Reeves, P. G.; Nielsen, F. H. \& Fahey Jr., G. C. AIN-93 purified diets for laboratory rodents: final report of the American Institute of Nutrition ad hoc writing committee on the reformulation of the AIN-76A rodent diet. J. Nutr., 123(11):1939-51, 1993.

Warensjö Lemming, E.; Byberg, L.; Melhus, H.; Wolk, A. \& Michaëlsson, $\mathrm{K}$. Long-term a posteriori dietary patterns and risk of hip fractures in a cohort of women. Eur. J. Epidemiol., 32(7):605-16, 2017.

Willeumier, J. J.; van der Linden, Y. M.; van de Sande, M. A. J. \& Dijkstra, P. D. S. Treatment of pathological fractures of the long bones. EFORT Open Rev., 1(5):136-45, 2017.

\section{Corresponding author:}

Marcio Babinski

Fluminense Federal University

Morphology Department

Biomedical Institute.

Rua Professor Ernani Mello, 101

São Domingos, Niterói

Rio de Janeiro

BRAZIL

Email:mababinski@gmail.com

Received: 17-03-2018

Accepted: 20-07-2018 